\title{
Strategic Promotion Tournaments and Worker Performance
}

\author{
Jed DeVaro* \\ Department of Labor Economics \\ Cornell University \\ Ithaca, NY 14853 \\ (607)255-8407 \\ FAX: 255-4496 \\ e-mail: devaro@cornell.edu
}

January 12, 2006

\begin{abstract}
In this analysis I study promotion schemes as human resource management strategies by which the firm can realize strategic goals by motivating workers to higher levels of effort and performance. Using information on promotions, wages, and performance for professional workers in a cross section of establishments in four metropolitan areas of the U.S., I investigate empirically the proposition that firms strategically organize promotion tournaments to motivate workers to higher levels of performance. I present evidence suggesting that relative performance of workers determines promotions, supporting the notion of internal promotion competitions in which internal hiring policies and fixed job slots combine to create competitions among workers of a given rank in a firm. I then estimate a structural model of promotion tournaments that simultaneously accounts for worker and firm behavior and how the interaction of these behaviors gives rise to promotions. The results are consistent with the prediction of tournament theory that workers are motivated by larger spreads.
\end{abstract}

\footnotetext{
* I have benefited considerably from discussions of this work with numerous colleagues. The comments of Chris Collins, Daniel Simon, the editor, and an anonymous referee were particularly helpful. David Rosenblum provided outstanding research assistance.
} 


\section{INTRODUCTION}

A firm's strategy with respect to managing its human resources is a central component in the execution of its overall business strategy. Significant research attention, both theoretical and empirical, has been devoted to analyzing the relationship between human resource practices and firm performance (see Wright et al., 2005 and the references therein). Alternative theoretical perspectives have been proposed to explain the link between human resource strategies and firm performance. One perspective is that taken in this study, namely that the firm can enhance worker performance through incentives provided by the firm's chosen HR strategy, such as the design of its compensation system (see, for example, Finkelstein and Hambrick, 1989; Fisher and Govindarajan, 1992; Galbraith and Merrill, 1991; Gomez-Mejia, 1992; Conyon, Peck, and Sadler, 2001). This view, in which the firm aims to influence worker behavior through its human resource strategy, has been termed the "behavioral perspective" in Snell (1992). An alternative perspective is the resource-based view, which emphasizes the role of idiosyncratic firm resources (in particular the human capital resources possessed by the organization's employees) in predicting firm performance (see, for example, Wernerfelt, 1984; Hitt and Ireland, 1986; Barney, 1991; Conner, 1991; Wright, McMahan, and McWilliams, 1994; Koch and McGrath, 1996; Wright, Dunford, and Snell, 2001). The resource-based view argues that human resource management strategies represent a source of competitive advantage, since they allow firms to develop a wealth of human capital, embodied in the firm's workers, that is both superior to that of competitors and also difficult to replicate by other firms (Porter, 1985). While the role of human resource management strategies in procuring and developing human capital within the firm as a means of achieving competitive advantage must be acknowledged, my attention in this analysis is on human resource management strategies as a means of influencing worker behavior. In particular, I consider the design of promotion policies as the means by which a profit-maximizing firm can create incentives for its workers, motivating them to appropriate levels of effort and performance.

Problems such as how to structure promotion paths across hierarchical levels in a firm, how to design a compensation system that fits well with the chosen structure of promotion paths, and how to motivate workers to higher levels of performance are of considerable strategic importance to the firm. Since promotions are typically associated with higher wages and other perks, the prospect of future promotion can serve as a strong motivator to workers to perform well in their current positions. To the extent that the firm controls the allocation of workers to jobs within the 
organization and can design promotion paths and the compensation profiles attached to them, the firm has at its disposal a powerful mechanism for motivating workers to higher levels of performance, potentially reaping gains in overall firm performance. The purpose of this paper is to investigate empirically the firm's use of promotions as incentive mechanisms. The investigation centers about three main questions. First, do firms tend to promote on the basis of relative worker performance, absolute worker performance, or a combination of the two? Second, do firms appear to design strategic promotion tournaments as a means of motivating workers to higher levels of performance? Third, do such tournaments have the intended incentive effects in that they do in fact motivate workers to higher performance levels? The evidence concerning the third question contributes to a literature on the effects of pay compression versus dispersion on organizational performance and strategy implementation (see, for example, Lawler, 1981; Pfeffer and Langton, 1993; Bloom, 1999; and Shaw, Gupta, and Delery, 2002).

More generally, the present discussion contributes to the literature in strategic human resource management (SHRM) linking human resource management practices to firm performance. The evolution of the SHRM literature in recent years suggests that the human resource system is an important means of helping an organization achieve a competitive advantage and that HR practices are more likely to enhance firm performance when they are internally aligned (Delery and Doty, 1996; Becker and Huselid, 1998). The internal alignment of HRM practices contributes to higher firm performance by eliciting, rewarding, and controlling worker behaviors that further the organization's strategic objectives (Arthur, 1992; Ulrich and Lake, 1991; Wright et al., 1994; Bowen and Ostroff, 2004). While the picture in the SHRM literature has become increasingly clear that HR practices can positively impact firm performance, the process by which these practices impact firm performance is less well understood. The intermediate stage between HR practices and firm performance has been referred to in the literature as a "black box" (Collins and Clark, 2003). A call for increased research attention to this intermediate stage has been made in Ferris et al. (1999). In this paper, I focus on the idea that a firm's HR practices (in particular its design of promotion paths and the compensation structure spanning the levels of the job hierarchy) enhance employees' motivation such that employees behave in ways that are instrumental to the implementation of the firm's business strategy.

The notion that HR practices impact firm performance through the intermediate step of enhancing worker motivation, by inducing workers to adopt behaviors that help the firm to achieve 
its strategic goals, was recently developed in work by Bowen and Ostroff (2004). This view emphasizes the idea that human resource practices serve as signals or communications to workers that allow them to understand the desired and appropriate responses and to share common beliefs about what behaviors are expected and rewarded (Guzzo and Noonan, 1994; Rousseau, 1995; Tsui et al., 1997) and draws on the following psychological theory put forth by Mischel (1973) describing the role of "strong situations" in controlling individual behavior: "Psychological 'situations' and 'treatments' are [strong] to the degree that they [1] lead all persons to construe the particular events the same way, [2] induce uniform expectancies regarding the most appropriate response pattern, [3] provide adequate incentives for the performance of that response pattern, and [4] instill the skills necessary for its satisfactory construction and execution."

Applying Mischel's theory to the HR context, Bowen and Ostroff (2004) argue that a "strong HRM system" can create an environment in which workers have uniform expectations about responses, expectations are clear about rewards and incentives for the desired worker responses (that is, those that are consistent with organizational strategic goals), and social influences further induce workers to comply with and conform to the desired set of behaviors. In addition to social relationships among workers, organizational leadership can influence the strength of the situation. For example, supervisors can serve the role of interpreting the strategic goals of the firm and conveying them to workers, or promoting high-quality informational exchanges with employees, thereby contributing to a common interpretation of the firm's strategic goals on the part of workers (Kozlowski and Doherty, 1989; Naumann and Bennett, 2000).

In the present context, I argue that strategic promotion tournaments can be interpreted as a central component of a "strong HRM system" designed by the firm to advance its strategic objectives. Returning to the four necessary conditions identified by Mischel (1973) for the existence of a strong situation that induces the desired worker behaviors, it is clear that the first two can be satisfied with properly-designed strategic promotion tournaments. The first condition involves inducing common perceptions on the part of workers about particular events (for example, events that reveal relevant information concerning or affecting the production process that could potentially be used by the workers to further the firm's strategic objectives) and the second involves inducing common expectations on the part of workers regarding the most appropriate way to respond to such events. Both are achieved through the firm's effective communication (either directly by supervisors or indirectly through informational signals sent by other aspects of the HR 
system) of the strategic goals and how appropriate worker behaviors can contribute to those goals. The third condition involves providing the workers with adequate incentives for the performance of the desired action. This is achieved directly by the structure of the tournament, which uses the prospect of promotion (and the increase in compensation that accompanies a promotion) as a means of creating workers incentives. For the tournament to be effective, it is essential that promotions be merit-based and that the notion of worker performance that is used as a basis to award promotions be linked clearly and directly to the firm's strategic goal in a way that is transparent to workers; that is, a worker's performance must be evaluated in terms of the degree to which the firm's strategic goals are enhanced by that worker's actions. The fourth and final condition for a strong situation is that workers are instilled with the skills necessary for the satisfactory execution of the desired behaviors. This is achieved not directly by the tournament scheme but rather by complementary HR practices (e.g. recruitment, screening, and training) that are aligned with promotion tournaments in an overall HRM system designed to further the firm's strategic objectives.

One can envision alternative means of creating incentives for workers, or more generally satisfying the conditions of a strong HR system. For example, the compensation system might be used alone rather than in conjunction with the job re-assignments that accompany promotions in a tournament. That is, workers could be compensated for high performance (meaning behavior that furthers the strategic goals of the firm) directly through performance bonuses, rather than through promotions. One appealing feature of promotions from the firm's perspective, however, is their high level of visibility to other workers. A promotion conveys information to workers about a reward for performance that furthers the strategic goals of the firm, and this information remains highly visible to other workers long after a promotion occurs. In contrast, performance bonuses are less visible to other workers; even if the amount of the bonus is publicly observable, the event is unlikely to persist for long in the memories of other workers. The point is that promotions might be a particularly effective means of rewarding workers for high performance in a highly visible fashion, thereby strengthening and sustaining the common set of beliefs among workers about what the strategic goals of the firm are and how they are rewarded.

\section{TOURNAMENT THEORY: BACKGROUND AND LITERATURE REVIEW}

The literature on the role of promotions in creating worker incentives is known as tournament theory, and an extensive body of theoretical work in this area has followed the initial 
paper by Lazear and Rosen (1981). Representative studies include Holmstrom (1982), Green and Stokey (1983), Nalebuff and Stiglitz (1983), Carmichael (1983), Malcomson (1984), Mookherjee (1984), O’Keeffe, Viscusi, and Zeckhauser (1984), Rosen (1986), McLaughlin (1988), Baker, Jensen, and Murphy (1988), Lazear (1989), and Zabojnik and Bernhardt (2001). The basic idea of a tournament is that workers of a given rank in an organization compete for promotion to the next level of the job hierarchy, with the promotion (and associated wage increase) awarded to the worker with the highest performance. The tournament prize is the difference in wages between the post-promotion and pre-promotion jobs, and this is chosen by the employer to induce the optimal level of worker effort. The sense in which the effort level is "optimal" is that it is the effort level that maximizes the firm's profit. If the firm chooses a wage spread that is too small, workers do not have strong incentives to compete for promotion and invest too little effort, resulting in lower levels of worker performance and ultimately lower levels of firm profit. Setting a wage spread that is too high is also detrimental to the firm. While a high wage spread generates strong worker incentives and high levels of performance, the fact that workers find high levels of effort unpleasant means that the firm must compensate this effort with higher wages. Beyond a certain point, it becomes too costly to the firm to motivate its workers to higher levels of performance, and profit suffers if the firm pushes workers too hard. The firm's problem, therefore, is to design promotion tournaments strategically so that they induce workers to choose the "optimal" levels of effort (and thereby performance) that ultimately maximize the firm's profit.

A key idea in tournament theory is that workers are promoted not on the basis of their level of performance in an absolute sense but rather on the basis of their performance relative to their peers. Competitions based on relative performance arise when internal hiring policies are combined with fixed job hierarchies. Throughout this discussion I refer to such situations as internal promotion competitions. There are various theoretical rationales for the internal hiring policies that give rise to internal promotion competitions. One possibility is that firms choose internal hiring over external hiring because of informational advantages. Hiring internally saves on the recruitment and screening costs associated with external hiring. Furthermore, incumbent workers might have valuable firm-specific knowledge that justifies filling a position through internal promotion. A second explanation, proposed by Waldman (2003), is that internal promotions may be understood as a rational response on the part of the firm to avoid the time inconsistency problem that arises when promotions are used for both job assignment and 
incentives. A third explanation is that internal hiring policies are used to motivate workers by the prospect of a promotion tournament as described by Lazear and Rosen (1981). This idea is developed in Chan (1996), where it is argued that in the context of tournaments, internal promotion policies serve as handicapping mechanisms that preserve incentives for a firm's current workers. An alternative way to maintain incentives in the face of external hiring would be to increase the size of the wage spread, but this creates problems of moral hazard on the part of the employer and also creates problems of sabotage as described by Lazear (1989).

Internal hiring alone, however, does not imply that relative performance determines promotions. In some cases there are not fixed job hierarchies creating internal competitions for a fixed number of promotions. Instead, everyone can, in principle, be promoted for good performance. This is the model used in banks, consulting firms, and in most research settings, where workers have job titles like "research associate", "senior research associate", "vice president", and "senior vice president", and often job tasks vary little across levels of the hierarchy. Even if all positions are filled with internal candidates, there are not internal competitions, and therefore promotions do not depend on relative performance. This view that job slots are flexible, with promotions determined only by absolute performance as it increases over time or is revealed to the employer over time, is assumed in the literature on promotions as job assignment mechanisms (see, for example, Waldman, 1984; Bernhardt, 1995; Gibbons and Waldman, 1999, 2006). Given the existence of both types of promotion processes, whether promotions based on relative performance occur frequently enough to be detected in the cross section is an empirical question, and I begin the analysis with this question.

Tournament theory takes the notion of an internal promotion competition and adds stronger implications arising from the optimizing behavior of workers and firms, in particular that firms optimally set the structure of compensation across the levels of the organizational hierarchy to create incentives. Thus, a promotion tournament is a special case of an internal promotion competition, with additional testable implications. The testable implications of tournament theory have been explored previously in two main branches of empirical literature: one focusing on the behavior of firms and the other on the behavior of workers.

Empirical studies focusing on firm behavior include O'Reilly, Main, and Crystal (1988), Main, O’Reilly, and Wade (1993), Lambert, Larcker, and Weigelt (1993), Eriksson (1999), Bognanno (2001), and Conyon, Peck, and Sadler (2001). Studies in this vein typically use firm- 
level data on corporate executives and ask whether firms choose compensation spreads to create incentives as suggested by tournament theory. Dependent variables in these studies are generally compensation spreads between levels of a job hierarchy. Two predictions of tournament theory are generally tested. The first is that wage spreads from promotion to a given level should be increasing in the number of workers at the next level down. The reasoning is that more workers create more competition, which has a negative effect on incentives that the principal counters by setting a larger wage spread. The second prediction, arising from Rosen (1986), is that the compensation structure is convex, meaning that the size of the wage spreads increases with the level of the job. Rosen analyzed an elimination tournament with a fixed job hierarchy and multiple rounds, finding that wage spreads increase with the level of the job because of the diminishing option value of successive promotions. Results in this strand of the literature have been mixed, with some results supportive of tournament theory and other results unsupportive.

Studies in the second branch of the empirical literature, focusing on worker behavior, ask whether tournaments have incentive effects, meaning that larger prizes imply higher levels of performance. These studies typically use data from sporting events (golf, bowling, tennis, NASCAR, et cetera) rather than from the context of greatest interest, namely promotion decisions in conventional firms. Representative papers include Ehrenberg and Bognanno (1990a,b), Becker and Huselid (1992), and Knoeber and Thurman (1994). In such studies a performance measure is regressed on some measure of the spread, and a positive coefficient on the spread is interpreted as evidence that tournaments have incentive effects. The spread is always treated as exogenous in such regressions. Conclusions from this strand of literature generally support the prediction that performance is increasing in the compensation spread rather than in compensation levels. The recent study by Audas, Barmby, and Treble (2004) is unusual in that it uses data on promotions, based on the personnel records of a large British financial sector employer. The authors find support for the predictions of tournament theory that effort is increasing in the spread and decreasing in the importance of "luck." Like the other studies in this branch of the literature, this one focuses only on worker behavior and treats the spread as exogenous in the worker's performance equation.

In this paper I diverge from both branches of previous empirical literature on tournament theory by considering the behavior of workers and firms jointly rather than in isolation. Using a cross-sectional employer data set containing information on promotions, wage spreads from 
promotion, worker performance, and worker, firm, and job characteristics, I estimate a structural tournament model treating performance, the wage spread, and promotions as endogenous variables. In contrast to the studies in the second branch of empirical literature that regress a measure of the agent's performance on a spread that is assumed to be exogenous, I treat this spread as endogenous in the performance equation since it is chosen by the firm to induce the optimal worker effort choice. I describe how the interaction of worker and firm behavior has testable implications that would be missed by considering only worker behavior or firm behavior individually.

I present two sets of empirical results in this paper. In the first, I provide evidence suggesting that promotions are determined by relative performance for workers in a cross section of establishments. In the second, I estimate a three-equation structural model on a subsample of professional workers, finding mixed support for the stronger predictions of tournament theory. A distinguishing feature of the data is the presence of employer-reported worker performance ratings. Such information is rare in data sets that span many establishments. The performance data allow a test of the incentive effects of tournaments in the context of greatest interest, namely promotion decisions in conventional firms. Prendergast (1999) criticizes the empirical incentives literature for focusing excessively on the contracts of workers for whom objective measures of output are readily available (e.g. CEOs, golfers, mutual fund managers, tree cutters, windshield installers, et cetera). As Prendergast argues, most people do not work in such jobs. Instead, most workers are evaluated on subjective criteria. Since the analysis in this paper is based on a broad cross section of workers for whom the relevant output measure is a subjective performance rating, this paper contributes results to the empirical incentives literature on the type of "typical jobs" that are rarely studied.

\section{SAMPLE AND DATA}

The data for this study are from the Multi-City Study of Urban Inequality (MCSUI), a cross-sectional employer telephone survey of 3510 establishments collected between 1992 and 1995 in four metropolitan areas: Atlanta, Boston, Detroit, and Los Angeles. The respondent was the owner in $14.5 \%$ of the cases, the manager or supervisor in $42 \%$, a personnel department official in $31.5 \%$, and someone else in $12 \%$. Two-thirds of the cases come from a probability sample stratified by establishment size (25\% 1-19 employees, 50\% 20-99 employees, 25\% 100 or more employees), drawn from regional employment directories provided by Survey Sampling, Inc. (SSI), primarily based on local telephone directories. The remaining third was drawn from the current or 
most recent employer reported by respondents in the corresponding MCSUI household survey. Screening identified a respondent who actually carried out hiring for the relevant position, and the survey instrument took 30-45 minutes to administer, with a response rate of 67\%. Sampling weights were constructed to correct for the complexities of the sampling scheme and weighted observations are a representative sample of firms, such as would occur if a random sample of employed people was drawn from each city. Holzer (1996) describes the data in more detail.

\section{MEASURES}

Many of the survey questions ask about the establishment's most recently hired worker. The key variables include whether the worker was promoted or was expected to be promoted within the next five years, the employer-reported subjective performance rating for this worker, the employer-reported subjective performance rating for the "typical" worker in that same job, the worker's wages before and after promotion or expected promotion, and characteristics of the worker and the job. The data also include worker and firm characteristics.

\section{Promotions and Expected Promotions}

I define dummy variables for both actual and expected promotions. The first, PROMOTE, equals one if a promotion occurred by the survey date and zero otherwise. The second, PROMEXP, equals one if a promotion was expected to occur within five years of the survey date and zero otherwise. Since the observations are a sample of recent hires, in many cases a promotion had not occurred by the survey date. About 8.0 percent of the workers had received a promotion by the survey date, and about 73.5 percent of the workers were expected to be promoted within the next five years. ${ }^{1}$

\section{Worker Performance and Relative Performance}

The measure of worker performance is the employer's answer to the following question about the most recently hired worker's performance in the job into which he was hired:

\footnotetext{
${ }^{1}$ These figures reflect sampling weights. Missing values reduce the total MCSUI sample size of 3510 to 3175 for promotions and to 2668 for expected promotions. I further omitted 350 cases for which the employer reported that no promotion was possible for the job in question, resulting in sample sizes of 2827 for promotions and 2341 for expected promotions. The 73.5 percent figure includes both workers who have already received a promotion and those who have not. Excluding those who have already received a promotion, about 71.8 percent of workers were expected to be promoted within the next five years $(\mathrm{N}=2093)$.
} 
"On a scale of 0-100 where 50 is average and 100 is the best score, how would you rate this employee's performance in this job?" A proxy for the performance of the most recently hired worker's competitors for promotion is provided by the following question: "On a scale of 0-100, how would you rate the typical employee's performance in this job?"

\section{Wage Spread}

Estimating the structural tournament model requires a measure of the wage spread, $S$, which is the difference in wages between the post-promotion and pre-promotion jobs. For workers who have received a promotion by the survey date, I define this spread as the difference between their current (post-promotion) wage and their starting wage, since this is the spread that is relevant for determining their performance level in the job into which they were hired. For workers who have not been promoted by the survey date, I define $\mathrm{S}$ as the difference between the wage they are expected to receive if they get promoted and their current wage. ${ }^{2}$

\section{Worker and Firm Characteristics}

Controls for worker and firm characteristics include dummies for whether the most recent hire has more than a high school degree or a college degree or more; the worker's tenure with the establishment; the fraction of high-skilled workers currently employed at the establishment; sex; age; race; establishment size; number of sites of operation for the firm; fraction of workers covered by a collective bargaining agreement at the establishment; duration of the establishment's operation at the current site ( 2 years or less, more than 2 years but no more than 5 , more than 5 years); dummies for whether the establishment is a franchise, whether it is for-profit, whether it employs temporary workers, whether it employs contract workers, whether it has formal procedures for posting internal job openings and soliciting application for filling them; 8 industry categories

\footnotetext{
${ }^{2}$ More precisely, the questions pertaining to the wages of the most recently hired worker are: $\mathrm{W}_{0}=$ "What is [this employee's] actual starting wage/salary?"

$\mathrm{W}_{1}=$ "What is his/her current wage/salary?"

$\mathrm{W}_{2}=$ "If promoted, what would this employee's wage or salary be?"

The reported time frame for these wages was either hourly, weekly, monthly, or annually, and I converted all responses to hourly wages measured in 1990 dollars, deflated using the CPI-UX. From these I defined the wage spread, S:$$
\begin{array}{rlrl}
\mathrm{S}_{\mathrm{i}} & =\mathrm{W}_{1 \mathrm{i}}-\mathrm{W}_{0 \mathrm{i}} & & \text { if } \text { PROMOTE }_{\mathrm{i}}=1 \\
& =\mathrm{W}_{2 \mathrm{i}}-\mathrm{W}_{1 \mathrm{i}} & & \text { if PROMOTE } \\
& &
\end{array}
$$ 
(manufacturing, services, wholesale trade, retail trade, finance, public administration, construction and mining, transportation); and the following occupation categories: ${ }^{3}$

Managerial: Includes Executive, Administrative, and Managerial Occupations

Scientists, Engineers, Doctors, Lawyers: Includes Surveyors and Architects; Natural Scientists and

Mathematicians; Social Scientists, Religious Workers; Health Diagnosing and Treating

Practitioners

Teachers, Librarians, Counselors: Also includes Writers, Artists, Entertainers, and Athletes

RNs, Pharmacists, and Dieticians: Also includes Therapists and Physicians' Assistants

Technologists and Technicians: Both "Health" and "Non-health"

Marketing and Sales Occupations

Administrative Support Occupations, including Clerical

Service Occupations

Craft, Construction, and Transportation Occupations: Includes Mechanics and Repairers;

Extractive Occupations; Precision Production Occupations; Material Moving Occupations

Production Workers and Laborers: Includes Handlers, Equipment Cleaners, and Helpers

Summary statistics for the full sample are displayed in Table 1.

-- INSERT TABLE 1 ABOUT HERE --

\section{PROMOTIONS AND RELATIVE WORKER PERFORMANCE}

To test whether promotions depend on relative performance, I estimate probit models using both promotions and expected promotions as dependent variables. The marginal effects of interest are those of $\mathrm{P}$ and $\mathrm{P}_{0}$, where $\mathrm{P}$ denotes the performance rating of the most recently hired worker in his starting job, and $\mathrm{P}_{0}$ denotes the performance rating of the typical worker in that same job. If promotions were based solely on absolute performance, we would expect that the marginal effect of $\mathrm{P}$ would be positive but the marginal effect of $\mathrm{P}_{0}$ should be near zero. That is, increases in the most recently hired worker's performance should improve his chances of promotion (and expected promotion), but increases in the performance of his competitors (as measured by the performance rating of the typical worker in that same position) should not harm his chances. On the other hand, if promotions are based on relative performance we expect to find a positive marginal effect of $\mathrm{P}$ and a negative marginal effect of $\mathrm{P}_{0}$, since a higher level of performance for the most recent hire's competition implies a reduction in this worker's chances for promotion or expected promotion.

\footnotetext{
${ }^{3}$ Technically there are 9 industry groups, since 2 of the observations are from the agriculture, forestry, and fishing industries. These are included in the reference group in models that include industry controls. Dropping these 2 observations from all analyses yields virtually identical results to those I report in the paper.
} 
Table 2 displays marginal effects from these probit models. ${ }^{4}$ As seen in Columns 1 and 3, the results suggest that relative performance matters in determining both promotions and expected promotions. A ten-point increase in $\mathrm{P}$ (roughly half of the standard deviation of $\mathrm{P}$ ) from the mean value of 78 , holding constant $\mathrm{P}_{0}$, is associated with an increase of about 2.6 percentage points in this worker's probability of promotion. Similarly, holding P constant, an increase from 76 to 86 in $\mathrm{P}_{0}$ is associated with a decrease of nearly 1.3 percentage points in the promotion probability. For expected promotions, a ten-point increase in $\mathrm{P}$ is associated with an increase of nearly 4.6 percentage points in the probability of expected promotion, and a ten-point increase in $\mathrm{P}_{0}$ is associated with about a 2.5 percentage point decrease in the probability of expected promotion. These results are upheld even in the presence of controls for worker and firm characteristics.

\section{-- INSERT TABLE 2 ABOUT HERE --}

It is interesting to note that the magnitude of the marginal effect of $\mathrm{P}$ exceeds that of $\mathrm{P}_{0}$, particularly in the models for actual promotions. This means that an increase of equal magnitude in both $\mathrm{P}$ and $\mathrm{P}_{0}$ would be associated with an increase in the predicted probabilities of promotion and expected promotion even though relative performance (as measured by the difference $\mathrm{P}-\mathrm{P}_{0}$ ) remains unchanged. An interpretation of this result is that absolute performance also matters in determining promotions, in addition to relative performance. Whereas tournament theory assumes job hierarchies with fixed job slots and promotions determined by relative performance, the job assignment literature assumes flexible job slots and promotions determined only by absolute performance. In a cross section that spans many types of jobs, it is therefore not surprising to find evidence of both types of promotion processes. To summarize, these results provide clear support for the notion that promotions are determined at least in part on the basis of relative performance.

\section{STRATEGIC PROMOTION TOURNAMENTS AND WORKER PERFORMANCE}

A promotion tournament is simply a particular case of an internal promotion competition, taking the idea that relative performance determines promotions and adding stronger implications concerning the chosen structure of compensation in the firm and how this affects worker incentives.

\footnotetext{
${ }^{4}$ Missing values scattered across the variables reduce the sample sizes in the probits. Also, note that in the expected promotion models I dropped those workers who had been promoted by the survey date.
} 
Tournament theory suggests that firms design the promotion system and compensation structure within the firm so as to motivate workers, thereby enhancing worker performance and ultimately improving firm performance. I now sketch the two-player tournament model as introduced in Lazear and Rosen (1981) and state the testable implications that emerge from it. Then I construct an empirical model that accounts for the optimizing behavior of both workers and firms and how these behaviors interact to produce promotion decisions.

\section{A Model of Strategic Promotion Tournaments}

Consider a firm with two identical, risk neutral workers and two jobs, a high-level job and a low-level job. Both workers compete for the high-level job, with this promotion (and its associated higher pay) being awarded to the worker who performs the best as a low-level worker during some observation period. Let the low-level job have a salary of $\mathrm{W}_{\mathrm{L}}$ and the high-level job have a salary of $\mathrm{W}_{\mathrm{H}}$, where $\mathrm{W}_{\mathrm{H}}>\mathrm{W}_{\mathrm{L}}$. Both of these wages are chosen in advance, before the firm's management observes worker productivity. The probability, $\rho$, of winning the promotion depends on performance, $\mathrm{P}$, which depends on the workers' levels of effort, $\mathrm{E}_{\mathrm{i}}$ and $\mathrm{E}_{\mathrm{j}}$, as follows:

$$
\begin{aligned}
& P_{i}=E_{i}+\varepsilon_{i} \\
& P_{j}=E_{j}+\varepsilon_{j}
\end{aligned}
$$

where the subscripts $i$ and $j$ denote the two competing workers and $\varepsilon_{\mathrm{i}}$ and $\varepsilon_{\mathrm{j}}$ denote the stochastic components of performance over which the workers have no control. These are assumed to have mean zero, variance $\theta$, and are independent across workers. While the original model exposited by Lazear and Rosen is cast in terms of worker output, in light of the empirical work that follows I use the closely related concept of worker performance instead.

The firm's expected profit is given by:

$$
\mathrm{E}(\pi)=\mathrm{E}_{\mathrm{i}}+\mathrm{E}_{\mathrm{j}}-\left(\mathrm{W}_{\mathrm{H}}+\mathrm{W}_{\mathrm{L}}\right) .
$$

We first consider the workers' labor supply conditions that dictate the chosen levels of effort, $\mathrm{E}_{\mathrm{i}}$ and $E_{j}$, and then discuss the firm's problem, which is to choose the optimal compensation scheme $\left(\mathrm{W}_{\mathrm{H}}\right.$ and $\mathrm{W}_{\mathrm{L}}$ ) to maximize profit, accounting for worker labor supply behavior and subject to a zero profit constraint. 


\section{The Workers' Problem}

Worker $i$ 's problem is to choose an effort level, $\mathrm{E}_{\mathrm{i}}$, knowing the prizes, $\mathrm{W}_{\mathrm{H}}$ and $\mathrm{W}_{\mathrm{L}}$, and the rules of the game but without communicating or colluding with worker $j$. Since the workers are identical, worker $j$ 's problem is the same. The players pre-commit to a chosen effort level without knowing who the opponent will be at the time all decisions are made; each worker plays against the (anonymous) "field." Worker $i$ chooses an effort level, $\mathrm{E}_{\mathrm{i}}$, to maximize the following expected utility function:

$$
\text { Expected Utility }=\mathrm{W}_{\mathrm{H}} \rho+\mathrm{W}_{\mathrm{L}}(1-\rho)-\mathrm{C}\left(\mathrm{E}_{\mathrm{i}}\right) .
$$

Here, $C\left(E_{i}\right)$ is the monetary cost of effort level $E_{i}$, where $C^{\prime}\left(E_{i}\right)>0$ and $C^{\prime \prime}\left(E_{i}\right)>0$. Noting that worker $i$ 's probability of winning the promotion to the high-level job, $\rho$, is a function of the effort level chosen, the first-order condition for this worker's problem is:

$$
\left(\mathrm{W}_{\mathrm{H}}-\mathrm{W}_{\mathrm{L}}\right) \partial \rho / \partial \mathrm{E}_{\mathrm{i}}=\mathrm{C}^{\prime}\left(\mathrm{E}_{\mathrm{i}}\right) \text {. }
$$

The left-hand side is the marginal return to effort, that is, the value of the prize $\left(\mathrm{W}_{\mathrm{H}}-\mathrm{W}_{\mathrm{L}}\right)$ multiplied by the marginal increase in the probability of winning the promotion for an increase in effort. The optimal labor supply condition states that the worker chooses the effort level that equates the marginal return of effort to its marginal cost.

The probability, $\rho$, that worker $i$ wins the promotion over worker $j$ is the probability that $i$ 's performance exceeds $j$ 's performance. That is,

$$
\rho=\operatorname{Prob}\left(E_{i}+\varepsilon_{i}>E_{j}+\varepsilon_{j}\right)=F\left(E_{i}-E_{j}\right)
$$

where $F$ is the cumulative distribution function of the random variable $\left(\varepsilon_{j}-\varepsilon_{i}\right)$ and $f$ is the associated density function. We can thus rewrite $\partial \rho / \partial E_{i}$ as $f\left(E_{i}-E_{j}\right)$, where we invoke the NashCournot assumptions that each worker takes the other's investment in effort as given since he plays against a market over which he has no influence. Since the workers are identical and therefore choose the same effort level, $f\left(E_{i}-E_{j}\right)$ can be rewritten as $f(0)$ and the labor supply condition is then:

$$
\left(\mathrm{W}_{\mathrm{H}}-\mathrm{W}_{\mathrm{L}}\right) \mathrm{f}(0)=\mathrm{C}^{\prime}\left(\mathrm{E}_{\mathrm{i}}\right) \text {. }
$$

assuming that the Nash equilibrium exists. Here, $f(0)$, the value of the density function at the mean, is inversely related to $\theta$, the variance of the stochastic determinants of performance.

The optimal labor supply condition and the convexity of the effort cost function give rise to two implications concerning the optimal effort level. First, the worker's level of effort is increasing in the wage spread $\left(\mathrm{W}_{\mathrm{H}}-\mathrm{W}_{\mathrm{L}}\right)$. That is, the larger the prize associated with the promotion the 
greater effort will be, other things equal. Furthermore, changes in the level of compensation that leave the spread unchanged should not affect effort. Wage levels only influence worker participation, which requires a nonnegative expected wage net of effort costs. Second, the effort level is decreasing in $\theta$, the variance of the stochastic component of performance. Intuitively, when random "luck" factors over which the worker has no control become more important determinants of the promotion probability, $\rho$, the marginal return to effort declines and the worker's incentives to exert effort are depressed. ${ }^{5}$

\section{The Firm's Problem}

The firm's problem is to select a compensation scheme $\left(\mathrm{W}_{\mathrm{H}}\right.$ and $\left.\mathrm{W}_{\mathrm{L}}\right)$ to maximize expected profits given the workers' labor supply behavior. Since the two workers are identical, symmetric equilibrium implies that they choose identical effort levels, $E_{i}=E_{j}$, and expected profits are given by:

$$
\mathrm{E}(\pi)=2 \mathrm{E}_{\mathrm{i}}-\left(\mathrm{W}_{\mathrm{H}}+\mathrm{W}_{\mathrm{L}}\right)
$$

The employer's problem is then to choose $\mathrm{W}_{\mathrm{H}}$ and $\mathrm{W}_{\mathrm{L}}$ so as to maximize:

$$
\begin{aligned}
& 2 \mathrm{E}_{\mathrm{i}}-\left(\mathrm{W}_{\mathrm{H}}+\mathrm{W}_{\mathrm{L}}\right) \\
& \text { subject to }\left(\mathrm{W}_{\mathrm{H}}+\mathrm{W}_{\mathrm{L}}\right) / 2=\mathrm{C}\left(\mathrm{E}_{\mathrm{i}}\right) .
\end{aligned}
$$

The constraint in this problem guarantees worker participation.

The first-order conditions are:

$$
\begin{aligned}
& 2\left[1-\mathrm{C}^{\prime}\left(\mathrm{E}_{\mathrm{i}}\right)\right] \partial \mathrm{E}_{\mathrm{i}} / \partial \mathrm{W}_{\mathrm{H}}=0 \\
& 2\left[1-\mathrm{C}^{\prime}\left(\mathrm{E}_{\mathrm{i}}\right)\right] \partial \mathrm{E}_{\mathrm{i}} / \partial \mathrm{W}_{\mathrm{L}}=0
\end{aligned}
$$

We have seen that the optimal labor supply condition (5) implies $\partial \mathrm{E}_{\mathrm{i}} / \partial\left(\mathrm{W}_{\mathrm{H}}-\mathrm{W}_{\mathrm{L}}\right)>0$, which further implies both $\partial \mathrm{E}_{\mathrm{i}} / \partial \mathrm{W}_{\mathrm{H}}>0$ and $\partial \mathrm{E}_{\mathrm{i}} / \partial \mathrm{W}_{\mathrm{L}}<0$. These facts in conjunction with (8a) and (8b) imply $\mathrm{C}^{\prime}\left(\mathrm{E}_{\mathrm{i}}\right)=1$; the marginal cost of effort equals the per-unit value of the product.

Finally, substituting $C^{\prime}\left(E_{i}\right)=1$ into the optimal labor supply condition gives:

$$
\left(\mathrm{W}_{\mathrm{H}}-\mathrm{W}_{\mathrm{L}}\right)=1 / \mathrm{f}(0) \text {. }
$$

\footnotetext{
${ }^{5}$ The first of these implications, namely that $\partial \mathrm{E}_{\mathrm{i}} / \partial\left(\mathrm{W}_{\mathrm{H}}-\mathrm{W}_{\mathrm{L}}\right)>0$, follows immediately from $(5)$ and the fact that $\mathrm{C}^{\prime}\left(\mathrm{E}_{\mathrm{i}}\right)$ is monotonically increasing in $\mathrm{E}_{\mathrm{i}}$. To see the second implication, namely that $\partial \mathrm{E}_{\mathrm{i}} / \partial \mathrm{f}(0)<0$, note that $\mathrm{f}(0)$ is simply the value of the density function evaluated at $\mathrm{E}_{\mathrm{i}}-\mathrm{E}_{\mathrm{j}}=0$. When "luck" disappears from the model, so that the distribution of $\varepsilon_{\mathrm{i}}$ becomes degenerate, $\mathrm{f}(0)$ goes to infinity. Similarly, when the variance of "luck" is high so that the luck distribution has long tails, $\mathrm{f}(0)$ becomes small. If $\mathrm{f}(0)$ increases so that the distribution becomes less disperse (luck matters less), the fact that $E_{i}$ must increase follows immediately from (5) and the fact that $C^{\prime}\left(E_{i}\right)$ is monotonically increasing in $E_{i}$.
} 
That is, the optimal wage spread chosen by the employer is increasing in $\theta$, the variance of the stochastic component of performance. Intuitively, as random factors matter more in dictating the probability of winning the promotion, a larger wage spread (or prize) is required to induce the worker to exert a given amount of effort.

\section{Testable Propositions of the Tournament Model}

In the empirical work I focus on the following testable propositions of the tournament model:

Testable Proposition 1: worker effort is increasing in the wage spread from promotion

Testable Proposition 2: effort is decreasing in $\theta$, the variance of the stochastic component of performance

Testable Proposition 3: the wage spread is increasing in $\theta$

Testable Proposition 4: promotions are determined by relative performance

The first three of these are implications of the tournament model, and the fourth is a key underlying assumption.

Given the nature of my data, I address neither the convexity of the compensation structure nor the effect of the number of players on the spread, both of which are predictions arising from extensions to the simple two-player model of Lazear and Rosen. Instead I focus on the basic ideas from Lazear and Rosen that promotions are determined by relative performance, that tournaments have incentive effects in that worker performance is increasing in the wage spread from promotion, and that wage spreads are chosen optimally by employers in light of the optimal labor supply behavior of workers.

\section{Empirical Model for Estimating the Tournament Promotion Model}

Beginning with worker behavior, consider a linear approximation to the labor supply function defined by (5) that defines effort as a function of the wage spread. Then substituting performance for effort, using (1a), the worker's linearized optimal performance function can be expressed as follows:

$$
P_{i}=\alpha_{0}+\alpha_{1} S_{i}+\mathbf{X}_{i} \alpha_{2}+\varepsilon_{1 i}
$$

where $\mathrm{P}_{\mathrm{i}}$ is worker performance, $\mathrm{S}_{\mathrm{i}}=\left(\mathrm{W}_{\mathrm{H}}-\mathrm{W}_{\mathrm{L}}\right)$ is the wage spread that the worker receives if promoted, $\mathbf{X}_{\mathrm{i}}$ is a vector of worker characteristics, and $\varepsilon_{1 \mathrm{i}}$ is a disturbance representing the 
unobserved determinants of performance. This is the equation that has been estimated in the branch of the empirical tournament literature that focuses on worker behavior, typically using data from sporting events and always treating the spread as exogenous.

Firm behavior is described by the optimal wage spread equation (9), where the wage spread is increasing in $\theta$, the variance of the stochastic component of performance. The optimal wage spread can be expected to vary by firm characteristics. Furthermore, anything observed by the employer that affects worker performance also affects the employer's choice of the spread since the firm chooses the spread to induce the optimal level of performance. That is, anything that appears on the right-hand side of (10) and that is observed by the employer also determines the employer's choice of wage spread, whether or not the econometrician observes the variables. A linearized version of the firm's optimal wage spread equation can thus be expressed as follows:

$$
S_{i}=\beta_{0}+\mathbf{F}_{i} \boldsymbol{\beta}_{1}+\mathbf{X}_{\mathrm{i}} \boldsymbol{\beta}_{2}+\varepsilon_{2 i}
$$

where $\mathbf{F}_{\mathrm{i}}$ is a vector of firm characteristics, $\mathbf{X}_{\mathrm{i}}$ is the vector of worker characteristics appearing in the performance equation, and $\varepsilon_{2 \mathrm{i}}$ is a disturbance representing unobserved determinants of the wage spread.

Testable Proposition 1 states that $\alpha_{1}$, the coefficient on the wage spread in the performance equation (10), should be positive. If the performance equation is estimated by ordinary least squares, as it has been in the previous literature, a behavioral interpretation cannot be attached to $\alpha_{1}$. We cannot say that the estimated $\alpha_{1}$ measures the amount by which worker performance increases in response to an increase in the spread, $S$, unless we assume $\operatorname{Cov}\left(\varepsilon_{1 \mathrm{i}}, \varepsilon_{2 \mathrm{i}}\right)=0$. This assumption is clearly untenable since both disturbances include common components, most notably $\theta$, the variance in the stochastic component of performance in $(1 \mathrm{a}, \mathrm{b})$. The tournament model predicts that worker performance is decreasing in $\theta$ and that the wage spread is increasing in $\theta$. More generally, factors that depress incentives cause the employer to increase the wage spread to counter the depressed incentives. ${ }^{6}$ Therefore, $\operatorname{Cov}\left(\varepsilon_{1 \mathrm{i}}, \varepsilon_{2 \mathrm{i}}\right)<0$ and consistent estimation of $\alpha_{1}$

\footnotetext{
${ }^{6}$ To see this, note that the structural disturbances may be decomposed as follows: $\varepsilon_{1 \mathrm{i}}=\tau \theta_{\mathrm{i}}+\varepsilon_{1 \mathrm{i}}{ }^{*}$ and $\varepsilon_{2 \mathrm{i}}=\varphi \theta_{\mathrm{i}}+\varepsilon_{2 \mathrm{i}}{ }^{*}$, where $\theta_{\mathrm{i}}$ is the variance in the stochastic determinants of worker $i$ 's performance, $\tau$ and $\varphi$ are parameters, and $\varepsilon_{1 i}{ }^{*}$ and $\varepsilon_{2 \mathrm{i}}{ }^{*}$ are disturbances that are assumed uncorrelated with $\theta_{\mathrm{i}}$. Hence, $\sigma_{12}=\operatorname{cov}\left(\varepsilon_{1 \mathrm{i}}, \varepsilon_{2 \mathrm{i}}\right)=\tau \varphi \operatorname{Var}\left(\theta_{\mathrm{i}}\right)+\operatorname{cov}\left(\varepsilon_{1 \mathrm{i}}{ }^{*}, \varepsilon_{2 \mathrm{i}}{ }^{*}\right)$. The optimal labor supply condition (5) implies $\tau<0$ and the firm's optimal wage spread equation (9) implies $\varphi>0$, so the term $\tau \varphi \operatorname{Var}\left(\theta_{\mathrm{i}}\right)$ is negative. Furthermore, $\operatorname{cov}\left(\varepsilon_{1 \mathrm{i}}{ }^{*}, \varepsilon_{2 \mathrm{i}}{ }^{*}\right)$ should also be negative since factors that depress worker effort and thereby performance also induce the firm, other things equal, to increase the wage spread to compensate. An example of such a factor is the number of players in the tournament, $\mathrm{N}_{\mathrm{i}}$. Although the theoretical model assumes a two-player game to simplify the exposition, the main results generalize to a tournament with $\mathrm{N}$ players with $\partial \mathrm{P}_{\mathrm{i}} / \partial \mathrm{N}_{\mathrm{i}}<0$
} 
requires a simultaneous equations estimation approach. Furthermore, since $\operatorname{Cov}\left(\varepsilon_{1 \mathrm{i}}, \varepsilon_{2 \mathrm{i}}\right)$ is an estimable parameter (namely $\sigma_{12}$ in the covariance matrix $\Sigma$ ), we can readily test the Testable Propositions 2 and 3. Together, they imply $\sigma_{12}<0$.

It remains to show how the optimizing behaviors of workers and firms, represented by Equations (10) and (11), interact to produce promotions. Consider a latent index, PROM ${ }^{*}$, that can be interpreted as a performance threshold for the most recently hired worker that, if exceeded, results in this worker's promotion. The observed dichotomous promotion variable is defined as follows:

$$
\begin{aligned}
\operatorname{PROM}_{\mathrm{i}} & =1 \text { if } \mathrm{P}_{\mathrm{i}}>\mathrm{PROM}_{\mathrm{i}}{ }^{*} \\
& =0 \text { if } \mathrm{P}_{\mathrm{i}} \leq \mathrm{PROM}_{\mathrm{i}}{ }^{*} .
\end{aligned}
$$

I refer to the latent threshold PROM" as the "bar". It depends on both firm and worker characteristics, and on the performance of the other workers competing with the most recently hired worker for the promotion. A linear specification of the latent promotion threshold is as follows:

$$
\mathrm{PROM}_{\mathrm{i}}^{*}=\gamma_{0}+\mathbf{F}_{\mathrm{i}} \gamma_{1}+\mathbf{X}_{\mathrm{i}} \gamma_{2}+\gamma_{3} \mathrm{P}_{0}+\varepsilon_{3 \mathrm{i}}
$$

where $\mathbf{F}_{\mathrm{i}}$ is a vector of firm characteristics, $\mathbf{X}_{\mathrm{i}}$ is a vector of worker characteristics, $\mathrm{P}_{0}$ is the performance of the competitors the most recently hired worker faces in the quest for promotion, and $\varepsilon_{3 \mathrm{i}}$ is a disturbance. The theory predicts that $\gamma_{3}$ should be positive (Testable Proposition 4), since the higher the performance of the worker's competition, the higher the bar and therefore the lower the probability of promotion. This simply says that promotions are determined by relative performance.

For the purpose of specifying the empirical model, it is convenient to define a second latent index, $\mathrm{I}^{*}=\mathrm{P}_{\mathrm{i}}-\mathrm{PROM}_{\mathrm{i}}{ }^{*}$, interpretable as the amount by which the most recently hired worker's performance exceeds the bar. This amount can be either positive or negative, so $\operatorname{Prob}\left[\operatorname{PROM}_{\mathrm{i}}=1\right]=\operatorname{Prob}\left[\mathrm{I}^{*}>0\right]$ and $\operatorname{Prob}\left[\operatorname{PROM}_{\mathrm{i}}=0\right]=\operatorname{Prob}\left[\mathrm{I}^{*} \leq 0\right]$. Substituting equation (11) into equation (10), and then substituting both the resulting reduced form performance equation and (12) into the equation for $\mathrm{I}^{*}$, we can write this latent index as:

$\mathrm{I}^{*}=\lambda_{0}+\mathbf{F}_{\mathrm{i}} \lambda_{1}+\mathbf{X}_{\mathrm{i}} \lambda_{2}+\lambda_{3} \mathrm{P}_{0}+v_{\mathrm{i}}$ where $\lambda_{0}=\left(\alpha_{0}+\alpha_{1} \beta_{0}-\gamma_{0}\right), \lambda_{1}=\left(\alpha_{1} \beta_{1}-\gamma_{1}\right), \lambda_{2}=\left(\alpha_{1} \beta_{2}+\alpha_{2}-\gamma_{2}\right), \lambda_{3}=-\gamma_{3}$, and $v_{i}=\varepsilon_{1 i}+\alpha_{1} \varepsilon_{2 i}-\varepsilon_{3 i}$.

The system of equations to be estimated is then:

and $\partial \mathrm{S}_{\mathrm{i}} / \partial \mathrm{N}_{\mathrm{i}}>0$ under certain conditions. To the extent that the structural disturbances include factors like $\mathrm{N}_{\mathrm{i}}$ the prediction that $\sigma_{12}<0$ is strengthened. 


$$
\begin{aligned}
& \mathrm{P}_{\mathrm{i}}=\alpha_{0}+\alpha_{1} \mathrm{~S}_{\mathrm{i}}+\mathbf{X}_{\mathrm{i}} \boldsymbol{\alpha}_{2}+\varepsilon_{1 \mathrm{i}} \\
& \mathrm{S}_{\mathrm{i}}=\beta_{0}+\mathbf{F}_{\mathrm{i}} \boldsymbol{\beta}_{1}+\mathbf{X}_{\mathrm{i}} \boldsymbol{\beta}_{2}+\varepsilon_{2 \mathrm{i}} \\
& \mathrm{I}_{\mathrm{i}}{ }^{*}=\lambda_{0}+\mathbf{F}_{\mathrm{i}} \lambda_{1}+\mathbf{X}_{\mathrm{i}} \lambda_{2}+\lambda_{3} \mathrm{P}_{0}+v_{\mathrm{i}} \\
& \text { PROM }_{\mathrm{i}}=1 \quad \text { if } \mathrm{I}_{\mathrm{i}}^{*} \geq 0 \\
& =0 \quad \text { otherwise }
\end{aligned}
$$

Given estimates of the parameters in this system, the $\gamma$ parameters of equation (12) can then be found by applying the relations following equation (13).

I make the conventional distributional assumption in models of this type that $\left(\varepsilon_{1 \mathrm{i}}, \varepsilon_{2 \mathrm{i}}, v_{\mathrm{i}}\right)$ is i.i.d. multivariate normal with mean vector zero and covariance matrix $\Sigma$. Let $\mathrm{f}$ denote the joint density function and $\mathrm{F}$ the cumulative distribution function; to avoid a proliferation of notation in deriving the likelihood function, I use $\mathrm{f}$ and $\mathrm{F}$ generically to denote densities and cumulative distribution functions. The next step is to define the terms $\mathrm{f}\left(\mathrm{P}_{\mathrm{i}}, \mathrm{S}_{\mathrm{i}} \mid \mathrm{PROM}_{\mathrm{i}}=1\right)$ and $\mathrm{f}\left(\mathrm{P}_{\mathrm{i}}, \mathrm{S}_{\mathrm{i}} \mid \mathrm{PROM}_{\mathrm{i}}=\right.$ 0 ) that appear in the two branches of the likelihood function, corresponding to the two possible values of PROM $\mathrm{M}_{\mathrm{i}}$. Defining $\mathrm{K}_{\mathrm{i}} \equiv \lambda_{0}+\mathbf{F}_{\mathrm{i}} \boldsymbol{\lambda}_{1}+\mathbf{X}_{\mathrm{i}} \lambda_{2}+\lambda_{3} \mathrm{P}_{0}$, we can write the first of these terms as follows:

$$
\begin{aligned}
& \left.\mathrm{f}\left(\mathrm{P}_{\mathrm{i}}, \mathrm{S}_{\mathrm{i}} \mid \mathrm{PROM}_{\mathrm{i}}=1\right)=\mathrm{f}\left(\mathrm{P}_{\mathrm{i}}, \mathrm{S}_{\mathrm{i}} \mid \mathrm{I}_{\mathrm{i}}{ }^{*}>0\right]\right)=\mathrm{f}\left(\varepsilon_{1 \mathrm{i}}, \varepsilon_{2 \mathrm{i}} \mid v_{\mathrm{i}}>-\mathrm{K}_{\mathrm{i}}\right) \times \mathbf{J}= \\
& \int_{-K_{i}}^{\infty} f\left(\boldsymbol{\varepsilon}_{1 i}, \boldsymbol{E}_{2 i}, \boldsymbol{V}_{i}\right) d \boldsymbol{V}_{i} \times \mathbf{J} / \operatorname{Pr} o b\left(\text { PROM }_{i}=1\right)= \\
& \int_{-K_{i}}^{\infty} f\left(\boldsymbol{V}_{i} \mid \boldsymbol{E}_{1 i}, \boldsymbol{E}_{2 i}\right) f\left(\boldsymbol{\varepsilon}_{1 i}, \boldsymbol{E}_{2 i}\right) d \boldsymbol{V}_{i} \times \mathbf{J} / \operatorname{Pr} o b\left({ }_{P_{R O M}}=1\right)= \\
& f\left(\mathcal{E}_{1 i}, \mathcal{E}_{2 i}\right) \Phi\left(\frac{K_{i}-\mu}{\sigma}\right) / \operatorname{Pr} o b\left(\text { PROM }_{i}=1\right)
\end{aligned}
$$

where $\mathbf{J}$, the Jacobian of transformation from $\left(\varepsilon_{1 \mathrm{i}}, \varepsilon_{2 \mathrm{i}}, \mathrm{v}_{\mathrm{i}}\right)$ to $\left(\mathrm{P}_{\mathrm{i}}, \mathrm{S}_{\mathrm{i}}, \mathrm{I}_{\mathrm{i}}{ }^{*}\right)$, is equal to 1 , $\mathrm{f}\left(\varepsilon_{1 \mathrm{i}}, \varepsilon_{2 \mathrm{i}}\right)$ is a bivariate normal density function, $\Phi$ denotes the standard normal cdf, and $\mu$ and $\sigma$ denote the mean and standard deviation of the conditional distribution of $\nu_{\mathrm{i}}$ given $\varepsilon_{1 \mathrm{i}}$ and $\varepsilon_{2 \mathrm{i}}$. The likelihood function, $\mathrm{L}$, is then given by: 
$L=\prod_{i=1}^{N}\left[\mathrm{f}\left(\mathrm{P}_{i}, \mathrm{~S}_{i} \mid \text { PROMOTE }_{\mathrm{i}}=1\right) \operatorname{Prob}\left(\text { PROMOTE }_{\mathrm{i}}=1\right)\right]^{\omega_{i} \text { PROMOTE }_{i}} \times$

$\left[\mathrm{f}\left(\mathrm{P}_{\mathrm{i}}, \mathrm{S}_{\mathrm{i}} \mid\right.\right.$ PROMOTE $\left._{\mathrm{i}}=0\right) \operatorname{Prob}\left(\right.$ PROMOTE $\left.\left.\left._{\mathrm{i}}=0\right)\right]\right) \omega_{i}^{(1-}$ PROMOTE $\left.i\right)$

where $\omega_{\mathrm{i}}$ is a sampling weight such that $\Sigma \omega_{\mathrm{i}}=\mathrm{N}$.

The usual rank conditions for identification hold in this model unless all elements of $\boldsymbol{\beta}_{1}$ are equal to zero. Therefore, it is the exclusion of firm characteristics from (14a) that identifies the performance equation. This identifying assumption can be justified on the grounds that employers know more about the firm than recently hired workers do, so workers are less able to assimilate information about firm characteristics into a decision function than firms are worker characteristics. This is especially so given that the typical recently hired worker has experience with only a small number of previous employers, if any at all, whereas the firm represents a wealth of historical information about how certain worker-types perform in given positions. With this exclusion restriction, all of the parameters in (14a) and (14b) are identified. Those in (14c) are identified only up to a scalar multiple since only the discrete realization of the endogenous promotion variable is observed and not its latent index. The three parameters in the covariance matrix $\Sigma$ that are associated with this equation are also identified only up to a scalar multiple. The usual identifying normalization $\sigma_{v v}=1$ is therefore assumed, and otherwise $\Sigma$ is unrestricted.

\section{ESTIMATION AND RESULTS}

The tournament model should be tested within a single, narrowly-defined, high-skilled occupational group. The rationale for focusing on the highest-skilled occupations is that promotion tournaments are more likely to occur in higher-skilled jobs, such as in management, than in lowskilled jobs. The reason is that output is typically easier to measure when the work is less skilled, making output-based incentive schemes like piece rates relatively more attractive. Tournaments, on the other hand, induce effort with only the requirement that relative output be measurable and become more attractive as incentive mechanisms in skilled positions where output is often harder to measure. Estimating the structural model on a sample of professional workers in effect gives the model its "best chance." In the MCSUI survey, employers were asked about the job into which the most recent worker was hired, and responses were recorded according to the 1980 SOC codes. I used these to construct a subsample of professional workers with 520 observations. Missing values 
scattered throughout the variables in the model reduce the usable sample size to 215 observations. According to the 1980 SOC codes these workers include administrative, engineering, scientific, teaching, and related occupations, including creative artists. Since the sample size is small relative to the number of parameters to be estimated, I did not use the full set of controls that were used in the analysis of Table 2; the analysis here omits industry controls. Furthermore, some of the control variables (tenure with the establishment, whether the establishment is a franchise, and establishment age) were found to have estimated effects near zero and large standard errors and I excluded these from the model on the basis of likelihood ratio tests.

Summary statistics for the subsample of professional workers are displayed in Table 3. Maximum likelihood estimates of the structural parameters are reported in Table 4. Recall that the tournament model has the following implications for the parameter estimates:

Testable Proposition 1: $\alpha_{1}>0$

Testable Propositions 2 and 3: $\sigma_{12}<0$

Testable Proposition 4: $\gamma_{3}>0$

All three parameters have the theoretically predicted signs, though only two achieve statistical significance at the ten percent level on a one-tailed test. That is, $\alpha_{1}=0.087(\mathrm{Z}=1.33), \sigma_{12}=-0.022$ $(\mathrm{Z}=0.73)$, and $\gamma_{3}=0.985(\mathrm{Z}=1.74)$. The result that $\gamma_{3}>0$ implies that relative performance matters for the promotion of skilled workers, just as was found in the earlier analysis for the entire cross section. The result that $\alpha_{1}>0$ suggests that tournaments do in fact have incentive effects, in that larger spreads are associated with higher levels of worker performance. This result has been found in the strand of the empirical tournament literature that focuses on worker behavior, though those studies are usually based on sporting events and have always treated the spread as exogenous. While the estimate of $\sigma_{12}$ is negative, since it is statistically insignificant it cannot be viewed as supporting the prediction that employers strategically choose the spread to induce higher levels of effort and performance.

\section{-- INSERT TABLE 3 ABOUT HERE -- \\ -- INSERT TABLE 4 ABOUT HERE --}

The tournament model predicts that performance is an increasing function of wage spreads rather than wage levels, although wage levels affect a worker's participation decision regarding 
whether to work for the firm. That is, an increase in the spread, holding the wage level constant, induces higher performance. This suggests that a test of the effect of the spread on performance necessitates controlling for wage levels. In fact, the wage level does not appear on the right-hand side of the performance equation (7a). By estimating the structural model only on a single occupational subgroup, I roughly control for wage levels by considering a relatively homogeneous group of workers with respect to skill level. Nevertheless, I also estimated the model including a measure of wage levels (in particular the average of the pre- and post-promotion wages) on the right-hand side of the performance equation, yielding results similar to those in Table 4.

\section{DISCUSSION AND CONCLUSION}

Although two of the three predictions of the tournament model are supported in the data, providing weak support for the tournament model, one should bear in mind the limitations of the data and the model when interpreting these results. First, there is considerable heterogeneity on both the worker and firm sides in the cross section of worker-establishment observations. I attempt to cope with this to the extent permitted by the data through control variables and through selection of a subsample of professional workers. Nonetheless, unmeasured heterogeneity could affect the results. Furthermore, a key variable in the tournament model that is unobserved in the data set is the number of workers competing with the most recently hired worker for promotion. While the model presented here is based on the simple two-player version of the tournament model presented by Lazear and Rosen (1981), in real world contexts the number of players competing for promotion will vary from tournament to tournament, potentially with implications for this analysis.

Other concerns arise from measurement issues. The difference in hourly wages is a crude proxy for the relevant theoretical notion of the spread that actually motivates workers. The relevant spread is best thought of as the difference in the present discounted value of total compensation between the two jobs, where the term "total compensation" is broadly defined to include the value of fringe benefits and all other non-pecuniary job characteristics. A related concern about the difference in hourly wages is that it is based on expected employer-reported wages rather than actual wages for all workers that have not been promoted by the survey date. A correction for classical linear measurement error in the spread is not feasible in this model due to the small sample and the large number of parameters to be estimated, and the potential for measurement error in the spread to bias the results presented here must be acknowledged. 
Regarding the fact that the correlation in unobserved determinants of worker performance and the spread is negative but statistically insignificant, a cautious interpretation is required in a cross section of promotion decisions across a wide range of firms, some of which may be engaging in promotion tournaments and some of which may not. It is quite plausible that some fraction of the establishments in the sample are engaged in promotion tournaments and that $\sigma_{12}$ is indeed negative for these establishments, whereas for other establishments in which the promotion process is not characterized by tournaments (perhaps job slots are flexible and promotions are awarded on the basis of either absolute performance or seniority) $\sigma_{12}$ is zero. That could explain why the estimate of $\sigma_{12}$, though negative as the tournament model predicts, is insignificant.

These limitations notwithstanding, I will offer an interpretation of the collective results of this analysis that I think is reasonable and that also suggests a promising direction for future research. One finding that clearly emerges from the analysis is that relative performance matters in determining promotions. Thus, the notion of an internal promotion competition in which internal hiring decisions combine with fixed job slots to produce promotions based on relative performance appears to describe average behavior in the cross section. The fixity of the job slots and the nature of tasks performed in each job is in many cases dictated by the production process and is therefore beyond the control of the decision-making entities of firms. That is, there are only some jobs, such as those in research, in which "everyone can be a vice president". In many other jobs there can only be one boss, and there is a fixed hierarchy with tasks associated at each level, as determined by the production process. In contrast to the fixity or flexibility of job slots, internal versus external hiring and promotions can be thought of as more flexible and more amenable to choice on the part of the firm. If a vacancy is created in a job hierarchy with fixed job slots, management can either fill the position with an external candidate or with an incumbent worker. The evidence presented here suggests that a good description of the average tendency is one in which fixed job slots are combined with internal hiring.

This leaves open the question of why firms hire and promote internally. One story is that promotions are used as incentive mechanisms, so the hiring must be from within to preserve worker incentives. This view is discussed by Chan $(1996,2006)$. The argument is that external hiring reduces incentives for current workers. The firm can respond either by increasing the wage spread from promotion, or by using an internal hiring policy as a handicap that favors internal workers. The latter policy avoids the problems of moral hazard and industrial politics that arise from large 
wage spreads. An alternative view presented by Waldman (2003) is that firms promote internally to avoid the time inconsistency problem arising when promotions are used to achieve both job assignment and incentive creation. That is, a policy of internal hiring allows a firm to credibly commit to the profit-maximizing promotion policy, while in the absence of such commitment the ex post optimal strategy for the firm would focus purely on job assignment. This would involve significant outside hiring, and internal incentives would suffer. Yet another motivation for internal hiring could be informational, in the sense that it is cheaper to obtain reliable information about existing workers than about outsiders. Furthermore, incumbent workers possess firm-specific institutional knowledge that can enhance their productivity in the promotion and reduce the costs of "learning the ropes" in the new position. That is, the major informational issue determining an employer's decision between internal and external hiring may be the observability of current worker output over that of prospective outside hires, rather than the unobservability of current worker output as in the tournament model. Since empirical evidence on the incidence of internal versus external hiring is relatively scant, producing such evidence and attempting to distinguish among the various theoretical explanations for internal hiring is a promising direction for future research.

Hiring internally when job slots are fixed necessarily creates some incentive effects of promotions, even if employers are not fixing the compensation structure ex ante to induce optimal worker performance as suggested by tournament theory. If workers know that the promotion is likely to be from within, and there are only a fixed number of slots, this necessarily creates incentives to win the promotion even if compensation is determined ex post after the firm observes worker productivity as in models of promotions as job assignment mechanisms. All that matters is that promotions be associated with large wage increases (and that they be based on merit) to create incentives; it does not matter whether the wage spreads are chosen by the firm in the manner prescribed by tournament theory. In fact, some extensions of tournament theory in recent years involve wage spreads arising through other mechanisms, such as the model of Zabojnik and Bernhardt (2001) in which the spread is determined by the market signal implied by promotion, as in Waldman (1984). If a firm can save on information costs by hiring internally, and if such internal hiring creates promotion incentive effects, it is plausible that the firm might sometimes pass up a more qualified outsider in favor of an insider. Finally, this interpretation of internal promotion competitions and the motivation for internal hiring would also be relevant in cases in 
which wages and wage spreads from promotions are subject to institutional constraints such as collective bargaining agreements, where choice of an optimal compensation structure to induce worker performance as in the tournament model is not even an option.

In summary, fixed job slots characterize many production processes. If combined with internal hiring policies, the result is an internal promotion competition in which relative performance determines promotions. Firms may choose internal promotions over external hiring for a number of reasons, either purposefully to create incentives for incumbent workers, to avoid the time inconsistency problem associated with using promotions to achieve both incentives and job assignment, or simply to economize on the informational advantages of hiring incumbent workers with firm-specific human capital over unknown outside candidates. To the extent that promotions are associated with higher wages, more interesting work, better offices, and other nonpecuniary compensation, workers will compete with each other to win these internal promotion competitions no matter what determines these compensation spreads. Hence, the evidence presented here in support of the prediction $\alpha_{1}>0$ suggests that workers respond to the incentives created by the prospect of a higher-paying promotion, even if the evidence fails to support the view (since $\sigma_{12}$ is statistically insignificant) that employers strategically choose the spread to induce the optimal worker effort choice.

\section{Conclusion}

The evidence in this analysis reveals that relative worker performance matters in determining promotions for workers in a cross section of establishments. This is true both unconditionally, and controlling for worker and firm characteristics. This suggests that internal promotion policies and fixed job slots combine to create internal promotion competitions in many organizations. After establishing this in the data, I empirically tested the stronger proposition that for professional workers these internal competitions are well described as promotion tournaments of the type discussed in Lazear and Rosen (1981). I constructed a structural model of promotion tournaments, treating worker performance, wage spreads, and promotion decisions as jointly endogenous, and estimated the model on a sample of professional workers. The structural estimates provide mixed support for the tournament model. While the evidence suggests that relative performance determines promotions and that larger wage spreads are associated with 
higher levels of worker performance, no statistically significant evidence is found of a negative correlation between unobserved determinants of worker performance and of the spread.

The structural approach distinguishes the present paper from the preceding empirical literature on tournament theory and provides a framework for future tests of the tournament model using more extensive cross sections or panels of firms. A main objective of this analysis has been to illustrate the value of recognizing the behavior of both the firm and workers simultaneously when constructing empirical models for confronting theory in strategic management with data. The fashion in the empirical literature has been to estimate descriptive regressions focusing on only one set of behaviors at a time, either the worker's or the firm's. For example, studies that test for incentive effects of tournaments treat the spread as exogenous in a single equation for performance. While the results presented here did not support a statistically significant negative correlation in the unobserved determinants of worker performance and the spread, at least such a finding would have been possible in this model since this correlation was treated as a free parameter to be estimated rather than implicitly constrained to equal zero. It is quite possible that in samples from new data sets the empirical framework presented here will yield the result predicted by tournament theory. For this reason, increased attention to empirical models that simultaneously incorporate the behaviors of both firms and workers appears to be a promising direction for future research.

I conclude the discussion with a comment on what might be learned from this analysis from the perspective of business managers, as opposed to scholars in the field of strategic management. Simply put, the results here provide evidence that workers respond to the incentives created by the firm's design of promotion schemes. Larger compensation spreads (as opposed to levels) are indeed associated with higher levels of worker performance, just as tournament theory predicts. This result has been found numerous times before in the context of sporting events such as golf, bowling, and NASCAR but, from the perspective of a business manager, is of even greater interest in the present context of promotion decisions in conventional firms. The reason this result should be of such interest is that, since managers set the compensation policy of the firm, the spread can be adjusted by the firm's management so that the prospect of promotion induces the appropriate worker incentives. Hence, the analysis here supports the broader notion that a firm's strategy with respect to the management of its human resources, in particular its decisions regarding the structure of compensation across levels of an organizational hierarchy, is an important means of achieving its overall business strategy. 


\section{REFERENCES}

Arthur JB. 1992. The Link Between Business Strategy and Industrial Relations Systems in American Steel Mini-Mills. Industrial and Labor Relations Review 45: 488-506.

Audas R, Barmby T, Treble J. 2004. Luck, Effort, and Reward in an Organizational Hierarchy. Journal of Labor Economics 22: 379-395.

Baker GP, Jensen MC, Murphy KJ. 1988. Compensation and incentives: practice vs. theory. Journal of Finance 43: 593-616.

Barney JB. 1991. Firm Resources and Sustained Competitive Advantage. Journal of Management 17: 99-120.

Becker B, Huselid, M. 1992. The Incentive Effects of Tournament Compensation Systems. Administrative Science Quarterly 37: 336-350.

Becker BE, Huselid MA. 1998. High Performance Work Systems and Firm Performance: A Synthesis of Research and Managerial Implications. In Research in Personnel and Human Resources Management Ferris GR (ed.) 16: 53-101.

Bloom M. 1999. The Performance Effects of Pay Dispersion on Individuals and Organizations. Academy of Management Journal 42: 25-40.

Bognanno ML. 2001. Corporate Tournaments. Journal of Labor Economics 19(2): 290-315.

Bowen DE, Ostroff C. 2004. Understanding HRM - Firm Performance Linkages: The Role of 'Strength' of the HRM System. Academy of Management Review 29: 203-221.

Carmichael HL. 1983. The Agent-Agents Problem: Payment by Relative Output. Journal of Labor Economics 1: 50-65.

Chan W. 2006. External Recruitment and Intrafirm Mobility. Economic Inquiry 44(1): 169-184.

Chan W. 1996. External Recruitment versus Internal Promotion. Journal of Labor Economics 14: $555-570$.

Collins CJ, Clark KD. 2003. Strategic Human Resource Practices, Top Management Team Social Networks, and Firm Performance: The Role of Human Resource Practices in Creating Organizational Competitive Advantage. Academy of Management Journal 46: 740-751.

Conner KR. 1991. A Historical Comparison of Resource-Based Theory and Five Schools of Thought within Industrial Economics: Do We Have a New Theory of the Firm? Journal of Management 17: 121-154.

Conyon MJ, Peck SI, Sadler GV. 2001. Corporate Tournaments and Executive Compensation: 
Evidence from the U.K. Strategic Management Journal 22(8): 805-815.

Delery JE, Doty DH. 1996. Modes of Theorizing in Strategic Human Resource Management: Test of Universalistic, Contingency, and Configurational Performance Predictions. Academy of Management Journal 39: 802-835.

Ehrenberg RG, Bognanno ML. 1990a. The Incentive Effects of Tournaments Revisited: Evidence from the European PGA Tour. Industrial and Labor Relations Review 43: 74S-88S.

Ehrenberg RG, Bognanno ML. 1990b. Do Tournaments Have Incentive Effects? Journal of Political Economy 98(6): 1307-24.

Eriksson T. 1999. Executive Compensation and Tournament Theory: Empirical Tests on Danish Data. Journal of Labor Economics 17(2): 262-280.

Ferris GR, Hochwarter WA, Buckley MR, Harrell-Cook G, Frink DD. 1999. Human Resource Management: Some New Directions. Journal of Management 25: 385-415.

Finkelstein S, Hambrick DC. 1989. Chief Executive Compensation: A Study of the Intersection of Markets and Political Processes. Strategic Management Journal 10(2): 121-134.

Fisher J, Govindarajan V. 1992. Profit Center Manager Compensation: An Examination of Market, Political and Human Capital Factors. Strategic Management Journal 13(3): 205217.

Galbraith CS, Merrill GB. 1991. The Effect of Compensation Program and Structure on SBU Competitive Strategy: A Study of Technology-Intensive Firms. Strategic Management Journal 12(5): 353-370.

Gibbons R, Waldman M. 1999. A Theory of Wage and Promotion Dynamics Inside Firms. Quarterly Journal of Economics 114: 1321-1358.

Gibbons R, Waldman M. 2006. Enriching a Theory of Wage and Promotion Dynamics Inside Firms. Journal of Labor Economics, forthcoming.

Gomez-Mejia LR. 1992. Structure and Process of Diversification, Compensation Strategy, and Firm Performance. Strategic Management Journal 13(5): 381-397.

Green JR, Stokey NL. 1983. A Comparison of Tournaments and Contracts. Journal of Political Economy 91: 349-364.

Guzzo RA, Noonan KA. 1994. Human Resource Practices as Communications and the Psychological Contract. Human Resource Management 33: 447-462.

Hitt M, Ireland D. 1986. Relationships Among Corporate Level Distinctive Competencies, 
Diversification Strategy, Corporate Strategy and Performance. Journal of Management Studies 23: 401-416.

Holmstrom B. 1982. Moral Hazard in Teams. Bell Journal of Economics 13: 324-340.

Holzer H. 1996. What Employer Want: Job Prospects for Less-Educated Workers. Russell Sage Foundation, New York.

Knoeber CR, Thurman WN. Testing the Theory of Tournaments: An Empirical Analysis of Broiler Production. Journal of Labor Economics 12(2): 155-179.

Koch MJ, McGrath RG. 1996. Improving Labor Productivity: Human Resource Management Policies Do Matter. Strategic Management Journal 17(5): 355-375.

Kozlowski SWJ, Doherty JL. 1989. Integration of Climate and Leadership: Examination of a Neglected Issue. Journal of Applied Psychology 74: 721-742.

Lambert RA, Larcker DF, Weigelt K. 1993. The Structure of Organizational Incentives. Administrative Science Quarterly 38(3): 438-461.

Lawler EE III. 1981. Pay and Organizational Development. Addison-Wesley: Reading, MA.

Lazear EP. 1989. Pay Equality and Industrial Politics. Journal of Political Economy 97: 561-580.

Lazear EP, Rosen S. 1981. Rank-Order Tournaments as Optimum Labor Contracts. Journal of Political Economy 89: 841-864.

Main B, O’Reilly C, Wade J. 1993. Top Executive Pay: Tournament or Teamwork. Journal of Labor Economics 11: 606-28.

Malcomson JM. 1984. Work Incentives, Hierarchy, and Internal Labor Markets. Journal of Political Economy 92: 486-507.

McLaughlin K. 1988. Aspects of Tournament Models: A Survey. In Research in Labor Economics 9, Ehrenberg R (ed.), 225-256. JAI: Greenwich, CT.

Mischel W. 1973. Toward a Cognitive Social Learning Conceptualization of Personality. Psychological Review 80: 252-283.

Mookherjee D. 1984. Optimal Incentive Schemes with Many Agents. Review of Economic Studies 51: 433-446.

Nalebuff BJ, Stiglitz, JE. 1983. Prizes and Incentives: Towards a General Theory of Compensation and Competition. Bell Journal of Economics 14: 21-43.

Naumann SE, Bennett N. 2000. A Case for Procedural Justice Climate: Development and Test of 
a Multilevel Model. Academy of Management Journal 43: 881-889.

O’Keeffe M, Viscusi K, Zeckhauser RJ. 1984. Economic Contests: Comparative Reward Schemes. Journal of Labor Economics 2: 27-56.

O’Reilly CA, Main BG, Crystal GS. 1988. CEO Compensation as Tournament and Social Comparison: A Tale of Two Theories. Administrative Science Quarterly 33: 257-274.

Pfeffer J, Langton N. 1993. The Effect of Wage Dispersion on Satisfaction, Productivity, and Working Collaboratively: Evidence from College and University Faculty. Administrative Science Quarterly 38: 382-407.

Porter M. 1985. Competitive Advantage. Free Press: New York.

Prendergast C. 1999. The Provision of Incentives in Firms. Journal of Economic Literature 37: 7 $-63$.

Rosen S. 1986. Prizes and Incentives in Elimination Tournaments. American Economic Review 76: 701-16.

Rousseau, DM. 1995. Psychological Contracts in Organizations. Sage: Thousand Oaks, CA.

Shaw JD, Gupta N, Delery JE. 2002. Pay Dispersion and Workforce Performance: Moderating Effects of Incentives and Interdependence. Strategic Management Journal 23: 491-512.

Snell SA. 1992. Control Theory in Strategic Human Resource Management: The Mediating Effect of Administrative Information. Academy of Management Journal 35(2): 292-327.

Tsui AS, Pearce JL, Porter LW, Tripoli AM. 1997. Alternative Approaches to EmployeeOrganization Relationship: Does Investment in Employees Pay Off? Academy of Management Journal 40: 1089-1121.

Ulrich D, Lake D. 1991. Organizational Capability: Creating Competitive Advantage. Academy of Management Executive 5(1): 77-91.

Waldman M. 2003. Ex Ante Versus Ex Post Optimal Promotion Rules: The Case of Internal Promotion. Economic Inquiry 41: 27-41.

Waldman M. 1984. Job Assignments, Signaling and Efficiency. Rand Journal of Economics 15: 255-270.

Wernerfelt B. 1984. A Resource Based View of the Firm. Strategic Management Journal 5: 171-180.

Wright PM, McMahan GC, McWilliams A. 1994. Human Resources and Sustained Competitive 
Advantage: A Resource-Based Perspective. International Journal of Human Resource Management 5: 301-326.

Wright PM, Dunford BB, Snell SA. 2001. Human Resources and the Resource-Based View of the Firm. Journal of Management 27(6): 701-721.

Wright PM, Gardner TM, Moynihan LM, Allen MR. 2005. The Relationship Between HR

Practices and Firm Performance: Examining Causal Order. Personnel Psychology 58: 409446.

Zabojnik J, Bernhardt D. 2001. Corporate Tournaments, Human Capital Acquisition, and the Firm Size - Wage Relation. Review of Economic Studies 68: 693-716. 
Table 1: Descriptive Statistics for the Full Sample

\begin{tabular}{|c|c|c|}
\hline & Mean & Standard Error \\
\hline \multicolumn{3}{|l|}{ Promotion Variables } \\
\hline PROMOTE & 0.075 & 0.005 \\
\hline PROMEXP & 0.667 & 0.013 \\
\hline \multicolumn{3}{|l|}{ Performance Variables } \\
\hline Performance $(\mathrm{P})$ & 78.337 & 0.427 \\
\hline Typical Performance $\left(\mathrm{P}_{0}\right)$ & 76.132 & 0.387 \\
\hline \multicolumn{3}{|l|}{ Worker Characteristics } \\
\hline More than High School & 0.255 & 0.010 \\
\hline College or more & 0.348 & 0.017 \\
\hline Fraction High Skilled & 0.314 & 0.012 \\
\hline Tenure (years) & 0.117 & 0.005 \\
\hline Male & 0.476 & 0.014 \\
\hline Age & 30.597 & 0.248 \\
\hline Black & 0.171 & 0.009 \\
\hline Hispanic & 0.143 & 0.010 \\
\hline Other Nonwhite & 0.081 & 0.010 \\
\hline \multicolumn{3}{|l|}{ Firm Characteristics } \\
\hline For Profit & 0.753 & 0.015 \\
\hline Franchise & 0.061 & 0.006 \\
\hline Number of Sites & 62.900 & 7.951 \\
\hline Establishment Size & 745.506 & 224.559 \\
\hline Union ( $\%$ covered in establishment) & 17.538 & 1.050 \\
\hline Temporary Workers? & 0.355 & 0.014 \\
\hline Contract Workers? & 0.297 & 0.012 \\
\hline$<=2$ Years in Operation & 0.083 & 0.006 \\
\hline$>2 \&<=5$ Years in Operation & 0.144 & 0.009 \\
\hline Internal Job Postings? & 0.597 & 0.013 \\
\hline Number of Observations & \multicolumn{2}{|r|}{3510} \\
\hline
\end{tabular}


TABLE 2: Probabilities of Promotion and Expected Promotion

\begin{tabular}{|c|c|c|c|c|}
\hline Dependent Variable & \multicolumn{2}{|c|}{ PROMOTE } & \multicolumn{2}{|c|}{ PROMEXP } \\
\hline Performance (P) & $\begin{array}{c}0.263 * * \\
(0.057)\end{array}$ & $\begin{array}{l}0.194 * * \\
(0.045)\end{array}$ & $\begin{array}{c}0.458 * * \\
(0.096)\end{array}$ & $\begin{array}{c}0.542 * * \\
(0.103)\end{array}$ \\
\hline Typical Performance $\left(\mathrm{P}_{0}\right)$ & $\begin{array}{c}-0.126 * * \\
(0.056) \\
\end{array}$ & $\begin{array}{c}-0.069 * \\
(0.041) \\
\end{array}$ & $\begin{array}{c}-0.251 * * \\
(0.116) \\
\end{array}$ & $\begin{array}{c}-0.263 * * \\
(0.127) \\
\end{array}$ \\
\hline \multicolumn{5}{|l|}{ Worker Characteristics } \\
\hline More than High School & $\bullet$ & $\begin{array}{l}0.007 \\
(0.012)\end{array}$ & • & $\begin{array}{l}-0.022 \\
(0.035)\end{array}$ \\
\hline College or more & $\bullet$ & $\begin{array}{c}-0.048 * * \\
(0.019)\end{array}$ & $\bullet$ & $\begin{array}{l}0.001 \\
(0.047)\end{array}$ \\
\hline Fraction High Skilled & $\bullet$ & $\begin{array}{r}-0.005 \\
(0.023)\end{array}$ & - & $\begin{array}{l}0.054 \\
(0.064)\end{array}$ \\
\hline Tenure (in years) & $\bullet$ & $\begin{array}{c}0.148 * * \\
(0.033)\end{array}$ & • & $\begin{array}{c}-0.672 * * \\
(0.125)\end{array}$ \\
\hline Male & • & $\begin{array}{l}0.015 \\
(0.012)\end{array}$ & $\bullet$ & $\begin{array}{l}0.036 \\
(0.035)\end{array}$ \\
\hline Age (in years) & $\bullet$ & $\begin{array}{l}-0.0004 \\
(0.0006)\end{array}$ & $\bullet$ & $\begin{array}{l}-0.003 \\
(0.002)\end{array}$ \\
\hline Black & $\bullet$ & $\begin{array}{c}0.027 * \\
(0.015)\end{array}$ & $\bullet$ & $\begin{array}{l}0.001 \\
(0.039)\end{array}$ \\
\hline Hispanic & $\bullet$ & $\begin{array}{l}0.014 \\
(0.015)\end{array}$ & - & $\begin{array}{l}0.067 \\
(0.046)\end{array}$ \\
\hline Other Non-White & • & $\begin{array}{c}0.050 * * \\
(0.021)\end{array}$ & • & $\begin{array}{l}0.099 \\
(0.063)\end{array}$ \\
\hline \multicolumn{5}{|l|}{ Firm Characteristics } \\
\hline For Profit & $\bullet$ & $\begin{array}{c}0.048 * * \\
(0.019)\end{array}$ & • & $\begin{array}{l}0.086^{*} \\
(0.050)\end{array}$ \\
\hline Franchise & • & $\begin{array}{c}-0.0004 \\
(0.021)\end{array}$ & $\bullet$ & $\begin{array}{l}-0.043 \\
(0.063)\end{array}$ \\
\hline Number of Sites (1000s) & • & $\begin{array}{l}0.002 \\
(0.010)\end{array}$ & • & $\begin{array}{l}0.133 \\
(0.083)\end{array}$ \\
\hline Estab. Size (1000s) & • & $\begin{array}{l}-0.003 \\
(0.006)\end{array}$ & $\bullet$ & $\begin{array}{l}0.046 \\
(0.035)\end{array}$ \\
\hline Union (fraction covered) & $\bullet$ & $\begin{array}{c}-0.039 * * \\
(0.017)\end{array}$ & $\bullet$ & $\begin{array}{c}-0.164 * * \\
(0.062)\end{array}$ \\
\hline Temporary Workers & $\bullet$ & $\begin{array}{l}0.007 \\
(0.011)\end{array}$ & $\bullet$ & $\begin{array}{l}0.057 \\
(0.037)\end{array}$ \\
\hline Contract Workers & $\bullet$ & $\begin{array}{l}0.007 \\
(0.012)\end{array}$ & - & $\begin{array}{l}0.026 \\
(0.037)\end{array}$ \\
\hline Internal Hiring & $\bullet$ & $\begin{array}{c}-0.033 * * \\
(0.011)\end{array}$ & $\bullet$ & $\begin{array}{l}0.099 * * \\
(0.034)\end{array}$ \\
\hline$<=2$ Years in Operation & $\bullet$ & $\begin{array}{c}-0.004 \\
0.017\end{array}$ & $\bullet$ & $\begin{array}{l}0.047 \\
(0.053)\end{array}$ \\
\hline$>2 \&<=5$ Years in Operation & • & $\begin{array}{l}0.007 \\
(0.015)\end{array}$ & $\bullet$ & $\begin{array}{l}0.011 \\
(0.041)\end{array}$ \\
\hline Occupation Controls & NO & YES & NO & YES \\
\hline Industry Controls & $\mathrm{NO}$ & YES & $\mathrm{NO}$ & YES \\
\hline $\mathrm{N}$ & 2425 & 1516 & 2174 & 1357 \\
\hline Pseudo $\mathrm{R}^{2}$ & 0.025 & 0.194 & 0.017 & 0.149 \\
\hline
\end{tabular}

Notes: Reported coefficients are probability derivatives $(\mathrm{dF} / \mathrm{dX})$ evaluated at the means. Standard errors are in parentheses. * and

** denote statistical significance at the $10 \%$ and $5 \%$ levels, respectively. Probits for expected promotions include only those

workers who had not received a promotion by the survey date. 
Table 3: Descriptive Statistics for Professionals

\begin{tabular}{|c|c|c|}
\hline & Mean & Standard Error \\
\hline \multicolumn{3}{|l|}{ Promotion Variable } \\
\hline PROMOTE & 0.052 & 0.013 \\
\hline \multicolumn{3}{|l|}{ Performance Variable } \\
\hline Performance $(\mathrm{P})$ & 81.199 & 1.115 \\
\hline \multicolumn{3}{|l|}{ Performance of Competition } \\
\hline Typical Performance $\left(\mathrm{P}_{0}\right)$ & 77.466 & 1.136 \\
\hline \multicolumn{3}{|l|}{ Wage Spread } \\
\hline Hourly Wage Difference (S) & 5.652 & 1.212 \\
\hline \multicolumn{3}{|l|}{ Worker Characteristics } \\
\hline More than High School & 0.166 & 0.023 \\
\hline College or more & 0.731 & 0.028 \\
\hline Fraction High Skilled & 0.496 & 0.025 \\
\hline Tenure (years) & 0.124 & 0.014 \\
\hline Male & 0.419 & 0.038 \\
\hline Age & 32.405 & 0.625 \\
\hline Black & 0.110 & 0.019 \\
\hline Hispanic & 0.110 & 0.030 \\
\hline Other Nonwhite & 0.103 & 0.020 \\
\hline \multicolumn{3}{|l|}{ Firm Characteristics } \\
\hline For Profit & 0.593 & 0.038 \\
\hline Franchise & 0.048 & 0.017 \\
\hline Number of Sites & 65.695 & 20.273 \\
\hline Establishment Size & 1712.825 & 911.414 \\
\hline Union ( $\%$ covered in establishment) & 21.784 & 3.264 \\
\hline Temporary Workers? & 0.454 & 0.038 \\
\hline Contract Workers? & 0.399 & 0.036 \\
\hline$<=2$ Years in Operation & 0.062 & 0.014 \\
\hline$>2 \&<=5$ Years in Operation & 0.119 & 0.022 \\
\hline Internal Job Postings? & 0.703 & 0.033 \\
\hline Number of Observations & \multicolumn{2}{|r|}{520} \\
\hline
\end{tabular}


Table 4: Estimates from Structural Tournament Model

\begin{tabular}{l|ccc}
\hline & PERFORMANCE & $S$ & PROM $^{*}$ \\
\hline \multirow{2}{*}{ S (wage spread) } & $\begin{array}{l}0.087^{*} \\
(0.066)\end{array}$ & $\bullet$ & $\bullet$ \\
\hline Worker Characteristics & & & \\
\hline \multirow{2}{*}{ More than high school } & 0.009 & 0.082 & -0.253 \\
& $(0.043)$ & $(0.135)$ & $(1.133)$ \\
\hline \multirow{2}{*}{ College or more } & -0.067 & $0.321^{* *}$ & 0.362 \\
& $(0.045)$ & $(0.160)$ & $(1.131)$ \\
\hline \multirow{2}{*}{ Fraction high skilled } & $0.139^{*} *$ & 0.221 & -0.624 \\
& $(0.040)$ & $(0.277)$ & $(1.132)$ \\
\multirow{2}{*}{ Age (divided by 10) } & 0.012 & -0.083 & -0.266 \\
& $(0.018)$ & $(0.068)$ & $(1.135)$ \\
\hline \multirow{2}{*}{ White } & -0.003 & $0.454^{* *}$ & 1.410 \\
& $(0.046)$ & $(0.188)$ & $(1.129)$ \\
\hline \multirow{2}{*}{ Male } & -0.005 & 0.291 & 0.711 \\
& $(0.035)$ & $(0.233)$ & $(1.131)$ \\
\hline
\end{tabular}

\section{Firm Characteristics}

\begin{tabular}{|c|c|c|c|}
\hline For Profit & $\bullet$ & $\begin{array}{c}0.264 \\
(0.263) \\
\end{array}$ & $\begin{array}{l}-1.008 \\
(0.733) \\
\end{array}$ \\
\hline Number of Sites (in thousands) & $\bullet$ & $\begin{array}{c}-0.052 \\
(0.034)\end{array}$ & $\begin{array}{l}-0.218 \\
(0.745)\end{array}$ \\
\hline Establishment Size (in thousands) & - & $\begin{array}{c}-0.019 \\
(0.016)\end{array}$ & $\begin{array}{c}0.183 \\
(0.744)\end{array}$ \\
\hline Union (fraction of workers covered) & $\bullet$ & $\begin{array}{c}0.008 \\
(0.220)\end{array}$ & $\begin{array}{c}0.073 \\
(0.743)\end{array}$ \\
\hline Temporary Workers? & $\bullet$ & $\begin{array}{c}-0.397 * * \\
(0.195)\end{array}$ & $\begin{array}{l}-0.275 \\
(0.758) \\
\end{array}$ \\
\hline Contract Workers? & & $\begin{array}{c}-0.015 \\
(0.144)\end{array}$ & $\begin{array}{c}0.148 \\
(0.743)\end{array}$ \\
\hline Internal Job Postings? & & $\begin{array}{c}0.368 \\
(0.271) \\
\end{array}$ & $\begin{array}{c}0.854 \\
(0.729) \\
\end{array}$ \\
\hline Performance of Typical Employee, $\mathrm{P}_{0}$ & $\bullet$ & $\bullet$ & $\begin{array}{c}0.985^{*} \\
(0.565)\end{array}$ \\
\hline Constant & $\begin{array}{c}0.695 * * \\
(0.063)\end{array}$ & $\begin{array}{c}-0.221 \\
(0.657) \\
\end{array}$ & $\begin{array}{c}1.550 \\
(1.119) \\
\end{array}$ \\
\hline$\sigma_{11}$ & \multicolumn{3}{|c|}{$\begin{array}{c}0.016 \\
(0.004)\end{array}$} \\
\hline$\sigma_{22}$ & \multicolumn{3}{|c|}{$\begin{array}{c}0.357 \\
(0.088) \\
\end{array}$} \\
\hline$\sigma_{12}$ & \multicolumn{3}{|c|}{$\begin{array}{c}-0.022 \\
(0.031) \\
\end{array}$} \\
\hline$\sigma_{1 v}$ & \multicolumn{3}{|c|}{$\begin{array}{c}-0.093 * * \\
(0.040)\end{array}$} \\
\hline$\sigma_{2 v}$ & \multicolumn{3}{|c|}{$\begin{array}{l}1.600 * * \\
(0.192)\end{array}$} \\
\hline
\end{tabular}

Note: Asymptotic standard errors are in parentheses. * and ** denote statistical

significance at the $10 \%$ and $5 \%$ levels, respectively. Subsample of professional workers. 